\title{
Ternary iron(II) complex with an emissive imidazopyridine arm from Schiff base cyclizations and its oxidative DNA cleavage activity $\dagger$
}

\author{
Arindam Mukherjee, Shanta Dhar, Munirathinam Nethaji and Akhil R. Chakravarty* \\ Department of Inorganic and Physical Chemistry, Indian Institute of Science, Bangalore, \\ 560012, India.E-mail: arc@ipc.iisc.ernet.in; Fax: 91-80-23600683; Tel: 91-80-22932533
}

Received 1st October 2004, Accepted 19th November 2004

First published as an Advance Article on the web 6th December 2004

The ternary iron(II) complex $\left[\mathrm{Fe}\left(\mathrm{L}^{\prime}\right)\left(\mathrm{L}^{\prime \prime}\right)\right]\left(\mathrm{PF}_{6}\right)_{3}(\mathbf{1})$ as a synthetic model for the bleomycins, where $\mathrm{L}^{\prime}$ and $\mathrm{L}^{\prime \prime}$ are formed from metal-mediated cyclizations of $N, N^{\prime}$-(2-hydroxypropane-1,3-diyl)bis(pyridine-2-aldimine) (L), is synthesized and structurally characterized by X-ray crystallography. In the six-coordinate iron(II) complex, ligands $\mathrm{L}^{\prime}$ and $\mathrm{L}^{\prime}$ show tetradentate and bidentate chelating modes of bonding. Ligand $\mathrm{L}^{\prime}$ is formed from an intramolecular attack of the alcoholic $\mathrm{OH}$ group of $\mathrm{L}$ to one imine moiety leading to the formation of a stereochemically constrained five-membered ring. Ligand $\mathrm{L}^{\prime \prime}$ which is formed from an intermolecular reaction involving one imine moiety of L and pyridine-2-carbaldehyde has an emissive cationic imidazopyridine pendant arm. The complex binds to double-stranded DNA in the minor groove giving a $K_{\text {app }}$ value of $4.1 \times 10^{5} \mathrm{M}^{-1}$ and displays oxidative cleavage of supercoiled DNA in the presence of $\mathrm{H}_{2} \mathrm{O}_{2}$ following a hydroxyl radical pathway. The complex also shows photo-induced DNA cleavage activity on UV light exposure involving formation of singlet oxygen as the reactive species.

\section{Introduction}

Bleomycins (BLMs) are the glycopeptide antitumor antibiotics that cleave DNA in an oxidative manner. ${ }^{1-3}$ The structure of BLMs primarily consists of three domains having different functional roles. It has a carbohydrate domain for cell permeability and for facilitating $\mathrm{O}_{2}$ binding, a chelation unit for binding to metal, viz. iron, which is also the oxygen binding site, and a C-terminus bithiazole unit with DNA binding affinity and sequence selectivity (Scheme 1). The structural and functional aspects of the BLMs-DNA interactions have earlier been studied using various BLM analogs/conjugates to determine the specific roles of different domains. ${ }^{4-8}$ In contrast, synthetic model iron complexes are rare, possibly due to the structural complexity of BLMs. ${ }^{9-15}$

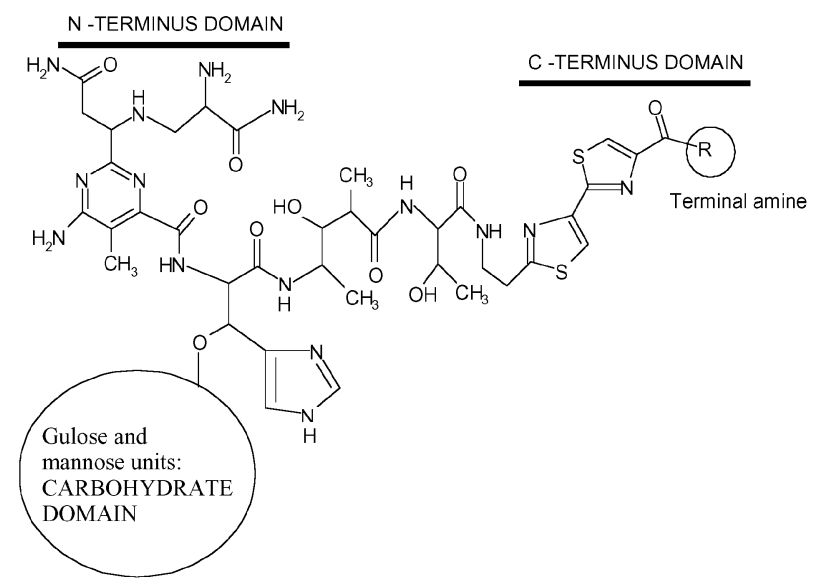

Scheme 1 Schematic structure of Bleomycins.

There are few reports on the synthetic model complexes for the metal binding site, i.e. the N-terminus domain. ${ }^{11-14}$ The

$\dagger$ Electronic supplementary information (ESI) available: Fig. S1: Visible spectral traces of $\mathbf{1}$ on treatment with $\mathrm{Ce}(\mathrm{IV})$ ion followed by ascorbate; Fig. S2: Structures of the five-membered ring of $L^{\prime}$ and the imidazopyridine ring of L". See http://www.rsc.org/suppdata/dt/b4/ b415864d/ only iron complex with a proposed structure that models both the $\mathrm{N}$ - and $\mathrm{C}$-terminus units was reported by Hertzberg and Dervan. ${ }^{10}$ They have shown that methidiumpropyl-EDTA in presence of ferrous ion and oxygen under in situ reaction cleaves DNA in an oxidative manner. In this paper, we present the synthesis and crystal structure of a ternary iron(II) complex $\left[\mathrm{Fe}\left(\mathrm{L}^{\prime}\right)\left(\mathrm{L}^{\prime \prime}\right)\right]\left(\mathrm{PF}_{6}\right)_{3}(\mathbf{1})$ which is formed serendipitously from novel Schiff base cyclizations involving the imine functionality of the potentially pentadentate Schiff base $N, N^{\prime}$-(2-hydroxypropane1,3-diyl)bis(pyridine-2-aldimine) (L) on reaction with ferric chloride in alcoholic medium in the presence of $\mathrm{NH}_{4} \mathrm{PF}_{6}$ (Scheme 2). Complex 1, with a semi-flexible cationic aromatic DNA-binder arm that shows fluorescence, exemplifies the first structurally characterized synthetic model for the N- and Cterminus domains of BLMs. Complex $\mathbf{1}$ efficiently cleaves supercoiled plasmid DNA in the presence of $\mathrm{H}_{2} \mathrm{O}_{2}$ or UV light.

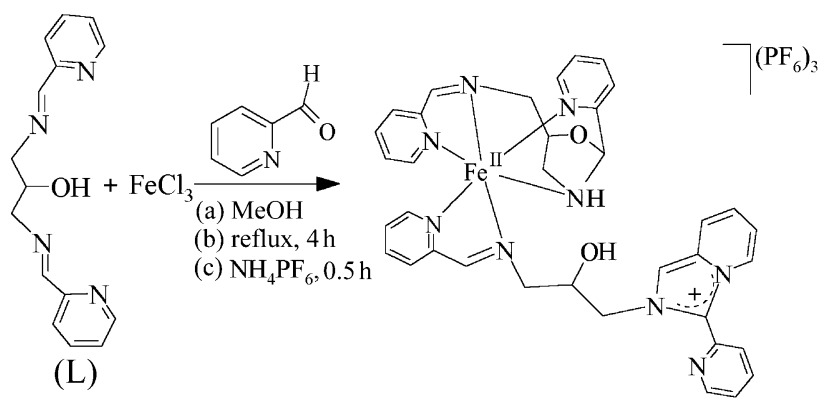

Scheme 2 Synthetic scheme for $\mathbf{1}$. $\mathrm{FeCl}_{3}$, L and pyridine-2-carbaldehyde are in $1.5,3.75$ and $1.8 \mathrm{mmol}$ quantity, respectively.

\section{Results and discussion}

\section{Synthesis and general aspects}

The reaction of $\mathrm{FeCl}_{3}$ with the potentially pentadentate Schiff base $N, N^{\prime}$-(2-hydroxypropane-1,3-diyl)bis(pyridine-2-aldimine) (L) forms 1 in $\sim 45 \%$ yield in the presence of $\mathrm{NH}_{4} \mathrm{PF}_{6}$ in an alcoholic medium. The yield is, however, significantly improved to $\sim 70 \%$ by a modified procedure in which pyridine-2carbaldehyde is added to the reaction mixture (Scheme 2). The crude purple product is found to contain a yellow paramagnetic impurity which is removed by column chromatography to isolate 
the analytically pure complex 1 . The complex is a $1: 3$ electrolyte and displays characteristic $\mathrm{PF}_{6}$ stretching bands in the IR spectrum. It shows electronic spectral $\mathrm{d}-\mathrm{d}$ bands at 516 and $592 \mathrm{~nm}$ and an emission band at $392 \mathrm{~nm}$ (317 nm excitation) in MeCN (Fig. 1). The complex is also emissive at $389 \mathrm{~nm}(315 \mathrm{~nm}$ excitation) in an aqueous medium. The emission intensity is found to increase slowly with time. After $c a .30 \mathrm{~min}$, it reaches its maximum. It is likely that the complex is susceptible to hydrolysis in the aqueous medium at the metal-bound imine bond of $\mathrm{L}^{\prime \prime}$ causing the imidazopyridine arm to slowly dissociate from the complex over a period of time.

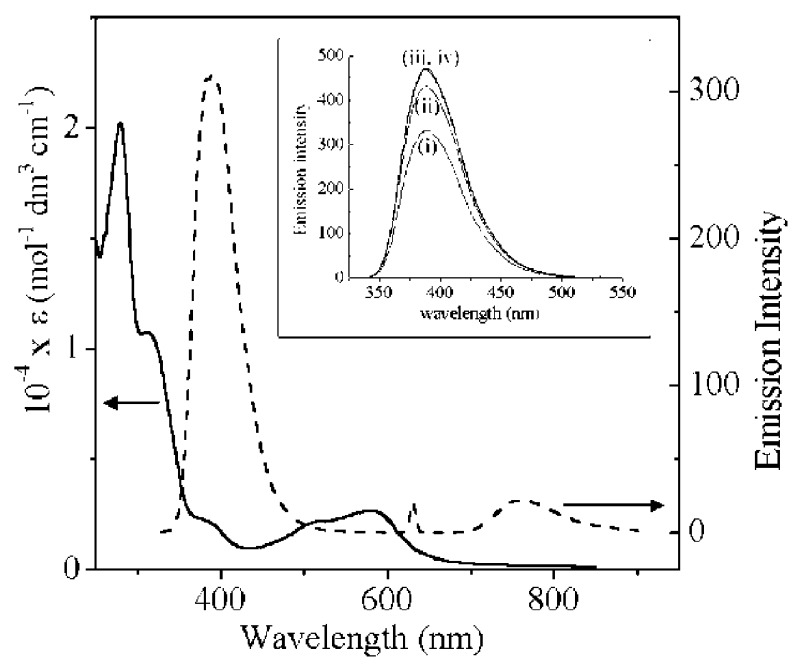

Fig. 1 UV-vis (-) and emission (---, $317 \mathrm{~nm}$ excitation) spectra of 1 in $\mathrm{MeCN}$. The inset shows the emission spectra of the complex in aqueous medium at different time intervals $[t=0 \mathrm{~min}$ (i); $10 \mathrm{~min}$ (ii); $20 \mathrm{~min}$ (iii); $30 \min (\mathrm{iv})]$.

The complex is redox active and displays a quasi-reversible cyclic voltammetric response assignable to the $\mathrm{Fe}(\mathrm{III}) / \mathrm{Fe}(\mathrm{II})$ couple at $0.98 \mathrm{~V} v s$. SCE $\left(\Delta E_{\mathrm{p}}, \sim 90 \mathrm{mV}\right.$ at $\left.50-500 \mathrm{mV} \mathrm{s}^{-1}\right)$ in MeCN-0.1 M TBAP (Fig. 2). ${ }^{16}$ It undergoes chemical oxidation on addition of $\mathrm{Ce}$ (IV) ion with a reduction of the intensity of the purple band to a colorless solution which regenerates $\mathbf{1}$ on reaction with sodium ascorbate in aqueous $\mathrm{MeCN}$ solvent (Fig. S1. ESI $\dagger$ )

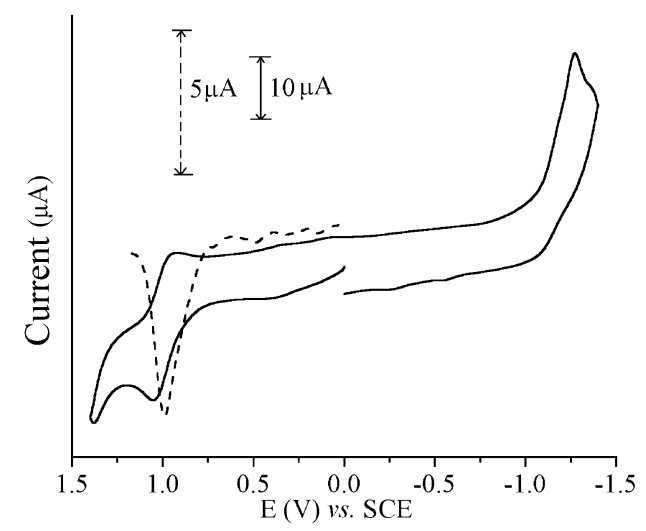

Fig. 2 The cyclic voltammogram (-) and differential pulse voltammogram (---) of 1 showing the $\mathrm{Fe}(\mathrm{III}) / \mathrm{Fe}(\mathrm{II})$ redox couple in $\mathrm{MeCN}-0.1 \mathrm{M}$ TBAP at $50 \mathrm{mV} \mathrm{s}^{-1}$ for $\mathrm{CV}$ and $5 \mathrm{mV} \mathrm{s}^{-1}$ for DPV (pulse height = $25 \mathrm{mV}$, drop time $=0.4 \mathrm{~s}$ ).

\section{Crystal structure}

Complex 1 has been structurally characterized by X-ray crystallography. The structure shows the presence of the cationic iron(II) complex and three $\mathrm{PF}_{6}$ anions in the crystallographic

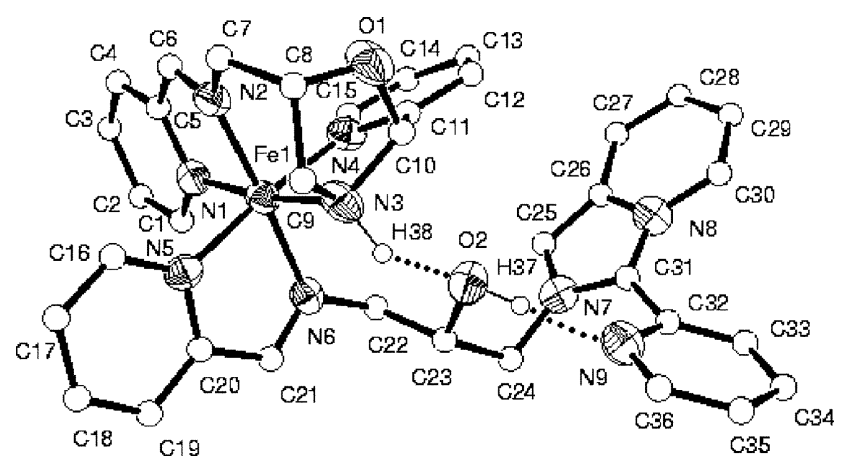

Fig. 3 A perspective view of the cationic complex in $\left[\mathrm{Fe}\left(\mathrm{L}^{\prime}\right)\left(\mathrm{L}^{\prime \prime}\right)\right]\left(\mathrm{PF}_{6}\right)_{3}$ (1) showing the pendant arm and the hydrogen bonding interactions.

asymmetric unit (Fig. 3). ${ }^{17}$ Selected bond distances and angles are given in Table 1 . In the ternary structure, $L^{\prime}$ and $L^{\prime \prime}$ display tetradentate and bidentate modes of binding, respectively, in an essentially octahedral $\mathrm{Fe}^{\mathrm{II}} \mathrm{N}_{6}$ coordination geometry. The av. Fe- $\mathrm{N}$ bond length is $\sim 2.0 \AA$ with the $\mathrm{Fe}(1)-\mathrm{N}(3)$ bond length $(2.036(6) \AA)$ being significantly longer than the rest. Both $L^{\prime}$ and $L^{\prime \prime}$ are formed from the Schiff base $L$ by metalpromoted Schiff-base cyclization reactions. Ligand $\mathrm{L}^{\prime}$ is formed from an intramolecular attack of the alcoholic $\mathrm{OH}$ group to one imine bond of $\mathrm{L}$ resulting in a stereochemically constrained five-membered ring that is expected to make the relatively long $\mathrm{Fe}(1)-\mathrm{N}(3)$ bond vulnerable to substitution in the DNA cleavage reactions (Fig. S2a, ESI $\dagger$ ). The mono-cationic $\mathrm{L}^{\prime \prime}$ is presumably formed from an intermolecular reaction involving one imine moiety of $\mathrm{L}$ with pyridine-2-carbaldehyde present in the reaction mixture.

Ligand $\mathrm{L}^{\prime \prime}$ has a long pendant arm whose flexibility is significantly reduced in the presence of hydrogen bonding interactions involving the $\mathrm{N}(3) \mathrm{H}(38)$ group of $\mathrm{L}^{\prime}$, the $\mathrm{O}(2) \mathrm{H}(37)$ group and the non-coordinated pyridine nitrogen atom $\mathrm{N}(9)$ of $\mathrm{L}^{\prime \prime}[\mathrm{N}(3) \cdots \mathrm{O}(2), 2.890(9) \AA ⿻ \mathrm{O}(2) \cdots \mathrm{N}(9), 2.838(9) \AA]$. Atoms $\mathrm{H}(37)$ and $\mathrm{H}(38)$ were located from the difference Fourier maps and refined isotropically. The fused five- and six-membered rings in the imidazo[1,5- $a]$ pyridine moiety of $\mathrm{L}^{\prime \prime}$ are essentially coplanar (dihedral angle: $\sim 1.0^{\circ}$ ) (Fig. S2b, ESI $\dagger$ ). The bond distances in this unit lie in the range of $1.348(11)$ to $1.439(10) \AA$ giving an av. distance of $1.38 \AA$ which is similar to the $\mathrm{C}-\mathrm{C}$ bond distances observed in the pyridyl rings (Table 2). Both the N(7) and $\mathrm{N}(8)$ atoms are planar showing a sum of three angles as $360^{\circ}$. This unit is mono-cationic and aromatic with the positive charge being delocalized on $\mathrm{N}(7)$ or $\mathrm{N}(8)$, giving a resonance structure (Scheme 2). There are four double bonds in this unit. Contribution of $2 \mathrm{e}^{-}$from the nitrogen atom makes $10 \pi$-electrons in total needed for aromaticity.

\section{DNA cleavage studies}

The binding of 1 to calf thymus (CT) DNA has been studied by fluorescence spectral method using the emission intensity of ethidium bromide (EB). EB does not show any emission

Table 1 Selected bond distances $(\AA)$ and bond angles $\left({ }^{\circ}\right)$ data for $\left[\mathrm{Fe}\left(\mathrm{L}^{\prime}\right)\left(\mathrm{L}^{\prime \prime}\right)\right]\left(\mathrm{PF}_{6}\right)_{3}(\mathbf{1})$

\begin{tabular}{lrlr}
\hline $\mathrm{Fe}(1)-\mathrm{N}(1)$ & $1.990(6)$ & $\mathrm{Fe}(1)-\mathrm{N}(4)$ & $2.007(5)$ \\
$\mathrm{Fe}(1)-\mathrm{N}(2)$ & $1.975(6)$ & $\mathrm{Fe}(1)-\mathrm{N}(5)$ & $1.991(5)$ \\
$\mathrm{Fe}(1)-\mathrm{N}(3)$ & $2.036(6)$ & $\mathrm{Fe}(1)-\mathrm{N}(6)$ & $1.995(5)$ \\
& & & \\
$\mathrm{N}(2)-\mathrm{Fe}(1)-\mathrm{N}(1)$ & $81.2(3)$ & $\mathrm{N}(5)-\mathrm{Fe}(1)-\mathrm{N}(4)$ & $174.4(2)$ \\
$\mathrm{N}(2)-\mathrm{Fe}(1)-\mathrm{N}(5)$ & $95.9(2)$ & $\mathrm{N}(6)-\mathrm{Fe}(1)-\mathrm{N}(4)$ & $93.2(2)$ \\
$\mathrm{N}(1)-\mathrm{Fe}(1)-\mathrm{N}(5)$ & $89.7(2)$ & $\mathrm{N}(2)-\mathrm{Fe}(1)-\mathrm{N}(3)$ & $91.5(3)$ \\
$\mathrm{N}(2)-\mathrm{Fe}(1)-\mathrm{N}(6)$ & $176.9(2)$ & $\mathrm{N}(1)-\mathrm{Fe}(1)-\mathrm{N}(3)$ & $171.4(2)$ \\
$\mathrm{N}(1)-\mathrm{Fe}(1)-\mathrm{N}(6)$ & $97.8(2)$ & $\mathrm{N}(5)-\mathrm{Fe}(1)-\mathrm{N}(3)$ & $95.5(2)$ \\
$\mathrm{N}(5)-\mathrm{Fe}(1)-\mathrm{N}(6)$ & $81.2(2)$ & $\mathrm{N}(6)-\mathrm{Fe}(1)-\mathrm{N}(3)$ & $89.8(2)$ \\
$\mathrm{N}(2)-\mathrm{Fe}(1)-\mathrm{N}(4)$ & $89.7(2)$ & $\mathrm{N}(4)-\mathrm{Fe}(1)-\mathrm{N}(3)$ & $83.5(2)$ \\
$\mathrm{N}(1)-\mathrm{Fe}(1)-\mathrm{N}(4)$ & $92.0(2)$ & & \\
\hline
\end{tabular}


Table 2 Selected bond distances $(\AA)$ for the cyclized moieties of $\left[\mathrm{Fe}\left(\mathrm{L}^{\prime}\right)\left(\mathrm{L}^{\prime \prime}\right)\right]\left(\mathrm{PF}_{6}\right)_{3}(\mathbf{1})$

Five-membered ring in $\mathrm{L}^{\prime}$

$\begin{array}{llll}\mathrm{O}(1)-\mathrm{C}(8) & 1.465(9) & \mathrm{C}(7)-\mathrm{C}(8) & 1.492(11) \\ \mathrm{O}(1)-\mathrm{C}(10) & 1.434(8) & \mathrm{C}(8)-\mathrm{C}(9) & 1.520(11) \\ \mathrm{N}(3)-\mathrm{C}(9) & 1.502(9) & \mathrm{C}(10)-\mathrm{C}(11) & 1.489(10) \\ \mathrm{N}(3)-\mathrm{C}(10) & 1.527(8) & & \end{array}$

\begin{tabular}{lcll}
\hline \multicolumn{4}{l}{ Imidazopyridine moiety in $\mathrm{L}^{\prime \prime}$} \\
\\
\hline $\mathrm{N}(7)-\mathrm{C}(25)$ & $1.363(8)$ & $\mathrm{C}(27)-\mathrm{C}(28)$ & $1.371(12)$ \\
$\mathrm{N}(7)-\mathrm{C}(31)$ & $1.370(8)$ & $\mathrm{C}(28)-\mathrm{C}(29)$ & $1.405(12)$ \\
$\mathrm{N}(8)-\mathrm{C}(26)$ & $1.408(9)$ & $\mathrm{C}(29)-\mathrm{C}(30)$ & $1.348(11)$ \\
$\mathrm{N}(8)-\mathrm{C}(30)$ & $1.416(9)$ & $\mathrm{C}(31)-\mathrm{C}(32)$ & $1.479(9)$ \\
$\mathrm{N}(8)-\mathrm{C}(31)$ & $1.359(8)$ & $\mathrm{C}(32)-\mathrm{C}(33)$ & $1.375(10)$ \\
$\mathrm{N}(9)-\mathrm{C}(32)$ & $1.364(9)$ & $\mathrm{C}(33)-\mathrm{C}(34)$ & $1.381(11)$ \\
$\mathrm{N}(9)-\mathrm{C}(36)$ & $1.334(11)$ & $\mathrm{C}(34)-\mathrm{C}(35)$ & $1.382(12)$ \\
$\mathrm{C}(25)-\mathrm{C}(26)$ & $1.368(10)$ & $\mathrm{C}(35)-\mathrm{C}(36)$ & $1.382(11)$ \\
$\mathrm{C}(26)-\mathrm{C}(27)$ & $1.439(10)$ & &
\end{tabular}

in the buffer medium due to fluorescence quenching by the solvent molecules. ${ }^{18}$ In the presence of CT DNA, it shows emission due to its intercalative binding to DNA. Addition of 1 with its cationic planar imidazopyridine moiety results in the competitive binding to DNA causing reduction of the emission intensity due to displacement of the EB from the bound to the free state (Fig. 4). The apparent binding constant $\left(K_{\text {app }}\right)$ is estimated as $4.1 \times 10^{5} \mathrm{M}^{-1}\left[K_{\text {app }}(\mathrm{EB})=10^{7} \mathrm{M}^{-1}\right] \cdot{ }^{19}$ The emission spectral behavior of complex 1 in the presence of CT DNA has been studied. The emission intensity is found to increase with time until it reaches a constant value after $c a .30$ min (Fig. 4).
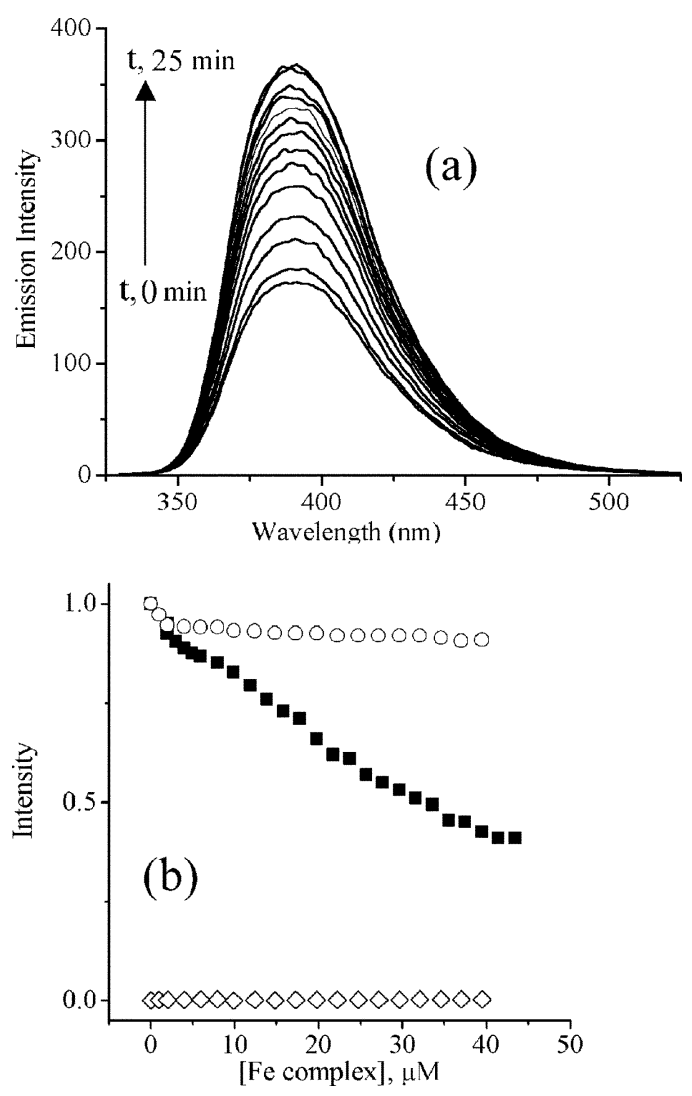

Fig. 4 (a) Emission spectral traces of $\left[\mathrm{Fe}\left(\mathrm{L}^{\prime}\right)\left(\mathrm{L}^{\prime \prime}\right)\right]\left(\mathrm{PF}_{6}\right)_{3}(\mathbf{1}, 5 \mu \mathrm{M})$ showing enhancement of intensity at $390 \mathrm{~nm}$ (excitation wavelength: $317 \mathrm{~nm}$ ) with time in the presence of CT DNA $(303 \mu \mathrm{M})$ in Tris- $\mathrm{HCl} / \mathrm{NaCl}$ buffer (50 mM, pH 7.2). (b) The effect of addition of $\mathbf{1}(\boldsymbol{\square})$ and $\mathrm{Na}$ [Fe(EDTA)] (O) to the emission intensity of $303 \mu \mathrm{M}$ calf thymus DNA-bound ethidium bromide $(1.3 \mu \mathrm{M})$ in a $5 \mathrm{mM}$ Tris- $\mathrm{HCl}$ buffer $(\mathrm{pH}, 7.2)$ at $25^{\circ} \mathrm{C}$ $(\diamond$, the emission intensities of the ethidium bromide in the absence of CT DNA but at different concentrations of $\mathbf{1}$ ).
The observation which is similar to that evidenced in the absence of DNA, suggests cleavage of the imidazopyridine arm from the complex. The results indicate significant quenching effect of the $\left\{\mathrm{FeL}^{\prime}\right\}^{2+}$ unit even in the absence of any $\pi$-conjugation between the metal-bound imine moiety and the imidazopyridine group of $\mathrm{L}^{\prime \prime}$.

The oxidative DNA cleavage activity of the complex was studied in the presence of $\mathrm{H}_{2} \mathrm{O}_{2}$ or on photo irradiation. The complex is cleavage inactive in the presence of reducing agents, but cleaves supercoiled (SC) pUC19 DNA when treated with $\mathrm{H}_{2} \mathrm{O}_{2}$ or on exposure to UV light (Figs. 5 and 6). Selected DNA cleavage data are given in Table 3 . Control experiments show that $\mathrm{H}_{2} \mathrm{O}_{2}$ or 1 alone, under aerobic conditions, is cleavage inactive in dark. A $30 \mu \mathrm{M}$ solution of 1 cleaves SC DNA ( 500 ng) to the extent of $\sim 93 \%$ on treatment with $53 \mu \mathrm{M} \mathrm{H}_{2} \mathrm{O}_{2}$. A significant cleavage of DNA is also observed at $10 \mu \mathrm{M}$ complex solution using $88 \mu \mathrm{M} \mathrm{H}_{2} \mathrm{O}_{2}$. Control experiments also reveal the minor groove binding of $\mathbf{1}$ as addition of distamycin completely inhibits the cleavage. A similar inhibition is observed in the presence of DMSO suggesting the possibility of the formation of $\cdot \mathrm{OH}$ radicals as the reactive species from probable hydroperoxo intermediate: $\left[\mathrm{Fe}^{\mathrm{III}}-\mathrm{OOH}^{-}\right]^{2+} \rightarrow\left[\mathrm{Fe}^{\mathrm{IV}}=\mathrm{O}\right]^{2+}+{ }^{\circ} \mathrm{OH} \cdot{ }^{20}$ DNA cleavage efficiency of $\mathbf{1}$ is significantly more than $\mathrm{Na}[\mathrm{Fe}(\mathrm{EDTA})]$ which shows only $\sim 26 \%$ cleavage, while 1 cleaves $\sim 75 \%$ using $25 \mu \mathrm{M}$ complex and $53 \mu \mathrm{M} \mathrm{H}_{2} \mathrm{O}_{2}$.

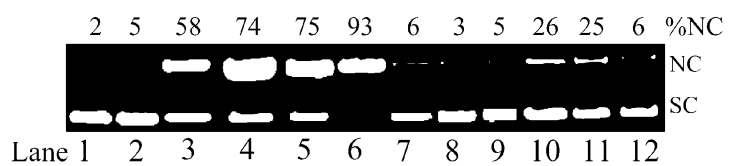

Fig. 5 Gel electrophoresis diagram showing the cleavage of SC pUC19 DNA $(0.5 \mu \mathrm{g})$ by 1 in Tris- $\mathrm{HCl} / \mathrm{NaCl}$ buffer $(\mathrm{pH} 7.2)$ in dark for $45 \mathrm{~min}$ reaction time: Lane 1, DNA control; lane 2, DNA $+\mathrm{H}_{2} \mathrm{O}_{2}(88 \mu \mathrm{M})$; lane 3 , DNA + $1(10 \mu \mathrm{M})+\mathrm{H}_{2} \mathrm{O}_{2}(70 \mu \mathrm{M}) ;$ lane 4 , DNA + $1(10 \mu \mathrm{M})+\mathrm{H}_{2} \mathrm{O}_{2}$ $(88 \mu \mathrm{M})$; lane 5, DNA + $1(25 \mu \mathrm{M})+\mathrm{H}_{2} \mathrm{O}_{2}(53 \mu \mathrm{M})$; lane 6, DNA + $1(30 \mu \mathrm{M})+\mathrm{H}_{2} \mathrm{O}_{2}(53 \mu \mathrm{M})$; lane 7 , DNA + distamycin $(100 \mu \mathrm{M})+\mathbf{1}$ $(25 \mu \mathrm{M})+\mathrm{H}_{2} \mathrm{O}_{2}(53 \mu \mathrm{M})$; lane 8, DNA + DMSO $(4 \mu \mathrm{L})+\mathbf{1}(25 \mu \mathrm{M})+$ $\mathrm{H}_{2} \mathrm{O}_{2}(53 \mu \mathrm{M})$; lane 9, DNA $+\mathrm{FeCl}_{3}(25 \mu \mathrm{M})+\mathrm{H}_{2} \mathrm{O}_{2}(53 \mu \mathrm{M})$; lane 10 $\mathrm{DNA}+\mathrm{Na}[\mathrm{Fe}($ EDTA $)](25 \mu \mathrm{M})+\mathrm{H}_{2} \mathrm{O}_{2}(53 \mu \mathrm{M})$; lane 11, DNA + 1 $(50 \mu \mathrm{M})+$ dithiothreitol (DTT, $5 \mathrm{mM})$; lane 12 , DNA + $1(50 \mu \mathrm{M})+$ 3-mercaptopropionic acid (MPA, $5 \mathrm{mM}$ ).

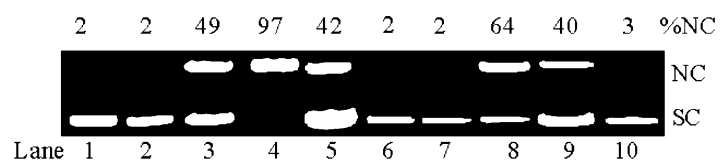

Fig. 6 Photocleavage of SC DNA $(0.5 \mu \mathrm{g})$ by 1. Lanes $1-9$ in air and lane 10 under argon. Lane 1, DNA control $(\lambda=312 \mathrm{~nm})$; lane 2, DNA + 1 (in dark); lane 3, DNA + $1(50 \mu \mathrm{M}, 312 \mathrm{~nm}, 5 \mathrm{~min})$; lane 4, DNA + $1(50 \mu \mathrm{M}, 312 \mathrm{~nm}, 10 \mathrm{~min})$; lane 5 , DNA + $1(50 \mu \mathrm{M})$; lane 6, DNA + $\mathrm{NaN}_{3}(100 \mu \mathrm{M})+\mathbf{1}$; lane 7 , DNA + L-histidine $(100 \mu \mathrm{M})+\mathbf{1}$; lane 8 , $\mathrm{DNA}+\mathrm{D}_{2} \mathrm{O}(14 \mu \mathrm{L})+1$; lane 9, DNA + DMSO $(4 \mu \mathrm{L})+1$; lane 10, DNA + 1 (under argon) [lanes 5-10: $1(50 \mu \mathrm{M}, 365 \mathrm{~nm}, 10 \mathrm{~min})]$.

The light-induced DNA cleavage has been studied at 312 and $365 \mathrm{~nm}$. A $50 \mu \mathrm{M} 1$ at $312 \mathrm{~nm}$ cleaves $\sim 97 \%$ of DNA $(\sim 500 \mathrm{ng})$ for an exposure of $10 \mathrm{~min}$. The extent of cleavage at $365 \mathrm{~nm}$ is $\sim 42 \%$ on 10 min photoexposure. Further investigations reveal an enhancement of cleavage in $\mathrm{D}_{2} \mathrm{O}$, complete inhibition in the presence of azide or L-histidine, and no apparent inhibition in DMSO. Complete inhibition is observed under argon. The results are indicative of the formation of singlet oxygen $\left({ }^{1} \mathrm{O}_{2}\right)$ as the reactive species in a type-II process by involving the cationic imidazopyridine moiety of $\mathrm{L}^{\prime \prime}$ as a photosensitizer: (i) $\left[\mathrm{Fe}^{\mathrm{II}}\left(\mathrm{L}^{\prime}\right)\left(\mathrm{L}^{\prime \prime}\right)\right]^{3+}(\mathrm{I})+\mathrm{h} v \rightarrow\left[\mathrm{Fe}^{\mathrm{II}}\left(\mathrm{L}^{\prime}\right)\left(\mathrm{L}^{\prime \prime}\right)^{*}\right]^{3+}\left(\mathrm{I}^{*}\right)$; (ii) $\mathrm{I}^{*}+{ }^{3} \mathrm{O}_{2} \rightarrow$ $\mathrm{I}+{ }^{1} \mathrm{O}_{2} \cdot{ }^{21}$ 
Table 3 Selected cleavage data ${ }^{a}$ of SC pUC19 (500 ng) DNA by 1 on chemical oxidation and photo-irradiation

\begin{tabular}{|c|c|c|c|c|c|c|}
\hline No & Reaction condition & {$[1] / \mu \mathrm{M}$} & {$\left[\mathrm{H}_{2} \mathrm{O}_{2}\right] / \mu \mathrm{M}$} & $\lambda / \mathrm{nm}$ & $t^{b} / \min$ & DNA cleavage $(\%)$ \\
\hline \multicolumn{7}{|c|}{ Chemical nuclease data } \\
\hline 1 & DNA control & - & - & - & - & 2 \\
\hline 2 & $\mathrm{DNA}+\mathrm{H}_{2} \mathrm{O}_{2}$ & - & 88 & - & - & 5 \\
\hline 3 & $\mathrm{DNA}+\mathbf{1}+\mathrm{H}_{2} \mathrm{O}_{2}$ & 10 & 88 & - & - & 74 \\
\hline 4 & $\mathrm{DNA}+\mathbf{1}+\mathrm{H}_{2} \mathrm{O}_{2}$ & 30 & 53 & - & - & 93 \\
\hline 5 & $\mathrm{DNA}+\mathrm{1}+\mathrm{DMSO}^{c}+\mathrm{H}_{2} \mathrm{O}_{2}$ & 25 & 53 & - & - & 3 \\
\hline 6 & $\begin{array}{l}\text { DNA }+ \text { distamycin } \\
\mathrm{H}_{2} \mathrm{O}_{2}\end{array}$ & 25 & 53 & - & - & 6 \\
\hline \multicolumn{7}{|c|}{ Photocleavage data } \\
\hline 7 & DNA control & - & - & 312 & 10 & 2 \\
\hline 8 & $\mathrm{DNA}+1$ & 50 & - & Dark & 10 & 2 \\
\hline 9 & $\mathrm{DNA}+1$ & 50 & - & 312 & 10 & 97 \\
\hline 10 & $\mathrm{DNA}+1$ & 50 & - & 365 & 10 & 42 \\
\hline 11 & $\mathrm{DNA}+\mathbf{1}+\mathrm{NaN}_{3}{ }^{e}$ & 50 & - & 365 & 10 & 2 \\
\hline 12 & $\mathrm{DNA}+\mathbf{1}+\mathrm{DMSO}^{c}$ & 50 & - & 365 & 10 & 40 \\
\hline
\end{tabular}

\section{Conclusion}

The ternary complex $\mathbf{1}$ is the first structurally characterized iron(II) complex modeling the $\mathrm{N}$ - and C-terminus domains of bleomycins. The ligands $\mathrm{L}^{\prime}$ and $\mathrm{L}^{\prime \prime}$ are formed from novel metalmediated Schiff base cyclizations of the Schiff base L. The DNA cleavage reaction of $\mathbf{1}$ involves the cationic arm as a minor groove binder and the redox active iron center to form the reactive hydroxyl species. Ligand $\mathrm{L}^{\prime \prime}$ with an emissive cationic pendant aromatic imidazopyridine ring acts as a photosensitizer. Isolation of $\mathbf{1}$ is of significance as imidazopyridines are known to be potential antitumor antibiotics. ${ }^{22-24}$

\section{Experimental}

All reagents and chemicals were purchased from commercial sources and used without further purifications except $\mathrm{MeCN}$, which was purified by standard procedures before use in electrochemical measurements. ${ }^{25}$ The Schiff base ligand $N, N^{\prime}-(2-$ hydroxypropane-1,3-diyl)bis(pyridine-2-aldimine) (L) was prepared by a reported method. ${ }^{26}$ The elemental analysis was done using Thermo Finnigan FLASH EA 1112 CHN analyser instrument. The IR and electronic spectral measurements were done using Perkin-Elmer Spectrum One FT-IR and Lambda 55 spectrometers, respectively. Cyclic and differential pulse voltammetric measurements were made at $25{ }^{\circ} \mathrm{C}$ on a EG\&G PAR 253 VersaStat potentiostat/galvanostat using a threeelectrode configuration consisting of a glassy carbon working, a platinum wire auxiliary and a saturated calomel reference (SCE) electrode. Ferrocene $\left(E_{\frac{1}{2}}=0.41 \mathrm{~V}\right)$ was used as a standard in $\mathrm{MeCN}-0.1 \mathrm{M}\left[\mathrm{Bu}_{4}^{\mathrm{n}}{ }_{4} \mathrm{~N}\right] \mathrm{ClO}_{4}$ (TBAP). Conductivity measurements were made at $25^{\circ} \mathrm{C}$ using a Control Dynamics conductivity meter.

\section{Preparation of $\left[\mathrm{Fe}\left(\mathrm{L}^{\prime}\right)\left(\mathrm{L}^{\prime \prime}\right)\right]\left(\mathrm{PF}_{6}\right)_{3}(1)$}

A $10 \mathrm{ml}$ methanolic solution of $\mathrm{FeCl}_{3}(0.243 \mathrm{~g}, 1.5 \mathrm{mmol})$ was added slowly to a magnetically stirred $15 \mathrm{ml}$ methanolic solution of the ligand $\mathrm{L}(1.0 \mathrm{~g}, 3.75 \mathrm{mmol})$. The solution was then refluxed under stirring for $15 \mathrm{~min}$ and pyridine-2carbaldehyde $(0.17 \mathrm{ml}, 1.8 \mathrm{mmol})$ was added. The mixture was refluxed for $4 \mathrm{~h}$. A $5 \mathrm{ml}$ methanolic solution of $\mathrm{NH}_{4} \mathrm{PF}_{6}$ $(1.16 \mathrm{~g}, 7.14 \mathrm{mmol})$ was then added to the reaction mixture and solution was heated for a further period of $30 \mathrm{~min}$. The solution was cooled to an ambient temperature. A purple solid was precipitated on slow concentration of the solution. The solid was isolated, washed with ethanol and dried in vacuo (yield: $1.17 \mathrm{~g}, \sim 70 \%$ ). The complex in an analytically pure form was isolated by column chromatography using neutral alumina column ( $45 \mathrm{~cm}$ length, $1.5 \mathrm{~cm}$ diameter) by loading $0.18 \mathrm{~g}$ of the crude product and elution was done using an $\mathrm{MeCN}-\mathrm{MeOH}$ mixture $(7: 3 \mathrm{v} / \mathrm{v})$ under nitrogen atmosphere. A minor yellow fraction as an impurity was eluted first. The major purple band containing complex 1 was eluted next. The complex was isolated in essentially quantitative yield after removal of the solvent. Anal. Calc. for $\mathrm{C}_{36} \mathrm{H}_{36} \mathrm{~F}_{18} \mathrm{FeN}_{9} \mathrm{O}_{2} \mathrm{P}_{3}: \mathrm{C}, 38.9 ; \mathrm{H}, 3.5 ; \mathrm{N}, 11.6$. Found: C, 38.7; H, 3.3; N, 11.3\%. FT-IR ( $\mathrm{KBr}$ phase), $\mathrm{cm}^{-1}$ : $3643 \mathrm{br}, 3418 \mathrm{br}, 3118 \mathrm{br}, 1613 \mathrm{~m}, 1550 \mathrm{w}, 1470 \mathrm{~m}, 1444 \mathrm{w}, 1294 \mathrm{~m}$, $1275 \mathrm{w}, 1253 \mathrm{w}, 1162 \mathrm{w}, 1115 \mathrm{w}, 1075 \mathrm{w}, 984 \mathrm{~m}, 840 \mathrm{vs}\left(\mathrm{PF}_{6}\right), 771 \mathrm{~s}$, 558s, 519w (br, broad; w, weak; m, medium; s, strong; vs, very strong). UV-vis in $\mathrm{MeCN}\left[\lambda_{\max } / \mathrm{nm}\left(\varepsilon / \mathrm{mol}^{-1} \mathrm{dm}^{3} \mathrm{~cm}^{-1}\right)\right]$ : 282 (19500), 321 (11300), 379 (5000), 516 (4600), 592 (6700). Conductance in $\mathrm{MeCN}\left[\Lambda_{\mathrm{M}} / \Omega^{-1} \mathrm{~cm}^{2} \mathrm{~mol}^{-1}\right]: 415$.

\section{X-Ray crystallography}

Crystal data for $\mathrm{C}_{36} \mathrm{H}_{36} \mathrm{~F}_{18} \mathrm{FeN}_{9} \mathrm{O}_{2} \mathrm{P}_{3}, M=1117.5$, triclinic, space group $P \overline{1}$ (no. 2), $a=9.449(5), b=15.793(8), c=$ 17.694(9) $\AA, \alpha=108.047(8), \beta=102.452(9), \gamma=107.097(8)^{\circ}$, $U=2259(2) \AA^{3}, Z=2, T=293(2) \mathrm{K}, D_{\mathrm{c}}=1.643 \mathrm{~g} \mathrm{~cm}^{-3}$, $R 1=0.0929, w R 2=0.2076$ for 4105 reflections with $I>2 \sigma(I)$ and 630 parameters $\left[R 1\left(F^{2}\right)=0.1856\right.$ (all data)]. Weighting scheme: $w=1 /\left[\sigma^{2}\left(F_{\mathrm{o}}{ }^{2}\right)+(0.1278 P)^{2}+2.4628 P\right]$, where $P=$ $\left[F_{\mathrm{o}}{ }^{2}+2 F_{\mathrm{c}}{ }^{2}\right] / 3$. X-Ray data from a Bruker SMART APEX CCD diffractometer. The structure was solved and refined by SHELX programs. ${ }^{27}$

Single crystals of complex 1 were obtained by vapour diffusion of diethyl ether into an acetonitrile solution of the complex. A prismatic single crystal was mounted on a glass fiber with epoxy cement. All the X-ray diffraction data were measured in frames with increasing $\omega$ (width of $0.3^{\circ}$ frame $^{-1}$ ) and with a scan speed at $15 \mathrm{~s} \mathrm{frame}^{-1}$ on a Bruker SMART APEX CCD diffractometer, equipped with a fine focus $1.75 \mathrm{~kW}$ sealed tube $\mathrm{X}$-ray source. Empirical absorption corrections were carried out using a multi-scan program. ${ }^{28}$ The structure was solved by the heavy atom method and refined by full-matrix least squares using the SHELX system of programs. ${ }^{27}$ All non-hydrogen atoms were refined anisotropically. The hydrogen atoms attached to carbon atoms in $\mathbf{1}$ were generated and assigned isotropic thermal parameters, riding on their parent carbon atoms, and used for structure factor calculation only. The hydrogen atoms of the $\mathrm{OH}$ and $-\mathrm{NH}$ groups were located from the difference Fourier maps and they were refined two cycles isotropically at the initial stage. At the final stage of refinement, their thermal parameters were only refined isotropically. The goodness-of-fit was 0.89 . The maximum shift/e.s.d. was 0.004 . 
CCDC reference number 240419.

See http://www.rsc.org/suppdata/dt/b4/b415864d/ for crystallographic data in CIF or other electronic format.

\section{DNA-binding and cleavage experiments}

The concentration of the calf thymus DNA $(125 \mu \mathrm{M})$ was determined from its absorption intensity at $260 \mathrm{~nm}$ with a known $\varepsilon$ value of $6600 \mathrm{dm}^{3} \mathrm{~mol}^{-1} \mathrm{~cm}^{-1}{ }^{29}$ The binding of complex 1 to calf thymus (CT) DNA was studied by fluorescence spectral method using the emission intensity of ethidium bromide (EB). The apparent binding constant $\left(K_{\text {app }}\right)$ value for 1 was estimated from the equation: $K_{\mathrm{EB}}[\mathrm{EB}]=K_{\text {app }}$ [complex] using the $K_{\text {app }}$ value of $\mathrm{EB}$ as $10^{7} \mathrm{M}^{-1}$. $^{19}$

The DNA cleavage activity of the complex was studied by agarose gel electrophoresis. Supercoiled pUC19 DNA $(6 \mu 1$, $\sim 500 \mathrm{ng}$ ) in Tris- $\mathrm{HCl}$ buffer $(50 \mathrm{mM}, \mathrm{pH} 7.2)$ containing $\mathrm{NaCl}$ $(50 \mathrm{mM})$ was treated with the complex in the presence or absence of additives. The oxidative DNA cleavage by the complex (10$30 \mu \mathrm{M}$ ) was studied in the presence of hydrogen peroxide of different concentrations varying from 53 to $88 \mu \mathrm{M}$. The sample was incubated first for $1 \mathrm{~h}$ at $37{ }^{\circ} \mathrm{C}$ and then added loading buffer $(25 \%$ bromophenol blue, $0.25 \%$ xylene cyanol, $30 \%$ glycerol $(3 \mu \mathrm{l}))$ and finally loaded on $0.8 \%$ agarose gel containing $1.0 \mu \mathrm{g} \mathrm{ml}^{-1}$ EB. Electrophoresis was carried out at $40 \mathrm{~V}$ for $2.0 \mathrm{~h}$ in Tris-acetate EDTA (TAE) buffer. Bands were visualized by UV light and photographed. The cleavage activity was measured by determining the ability of the complex in relaxing the SC DNA to its nicked circular (NC) form. The proportion of DNA in the $\mathrm{SC}$ and $\mathrm{NC}$ form after electrophoresis was estimated quantitatively from the intensities of the bands using a UVITEC Gel Documentation System with due correction of the low level of $\mathrm{NC}$ present in the original sample and the low affinity of EB binding to SC compared to NC and linear forms of DNA. ${ }^{30}$ The photo-induced pUC19 DNA cleavage studies were carried out using monochromatic UV lights of $312 \mathrm{~nm}$ ( $96 \mathrm{~W}$ total wattage) and $365 \mathrm{~nm}(12 \mathrm{~W})$. Control experiments were done using different reagents such as sodium azide $(100 \mu \mathrm{M}), \mathrm{DMSO}$ $(4 \mu \mathrm{L}), \mathrm{D}_{2} \mathrm{O}(14 \mu \mathrm{L})$, L-histidine $(100 \mu \mathrm{M})$, distamycin $(100 \mu \mathrm{M})$ added to SC DNA prior to the addition of the complex.

\section{Acknowledgements}

We thank the Department of Science and Technology, Government of India, for funding and the diffractometer facility, the Council of Scientific and Industrial Research, New Delhi, for funding, and the Alexander von Humboldt Foundation, Germany, for donation of an electroanalytical system.

\section{References}

1 H. Umezawa, Prog. Biochem. Pharmacol., 1976, 11, 18.

2 R. M. Burger, Chem. Rev., 1998, 98, 1153.

3 S. E. Wolkenberg and D. L. Boger, Chem. Rev., 2002, 102, 2477.
4 D. L. Boger and H. Cai, Angew. Chem., Int. Ed., 1999, 38, 448.

5 M. Otsuka, T. Masuda, A. Haupt, M. Ohno, T. Shiraki, Y. Sugiura and K. Maeda, J. Am. Chem. Soc., 1990, 112, 838.

6 C. J. Thomas, M. M. McCormick, C. Vialas, Z.-F. Tao, C. J. Leitheiser, M. J. Rishel, X. Wu and S. M. Hecht, J. Am. Chem. Soc., 2002, 124, 3875.

7 A. K. Choudhury, Z.-F. Tao and S. M. Hecht, Org. Lett., 2001, 3, 1291.

8 M. J. Rishel, C. J. Thomas, Z.-F. Tao, C. Vialas, C. J. Leitheiser and S. M. Hecht, J. Am. Chem. Soc., 2003, 125, 10194.

9 G. Pratviel, J. Bernadou and B. Meunier, Adv. Inorg. Chem., 1998 , 45, 251.

10 R. P. Hertzberg and P. B. Dervan, J. Am. Chem. Soc., 1982, 104, 313.

11 R. J. Guajardo, F. Chavez, E. T. Farinas and P. K. Mascharak, J. Am. Chem. Soc., 1995, 117, 3883.

12 C. Nguyen, R. J. Guajardo and P. K. Mascharak, Inorg. Chem., 1996, 35,6273 .

13 D. Y. Dawson, S. E. Hudson and P. K. Mascharak, J. Inorg. Biochem., 1992, 47, 109.

14 I. Lippai, R. S. Magliozzo and J. Peisach, J. Am. Chem. Soc., 1999, 121, 780 .

15 H. Kurosaki, Y. Ishikawa, K. Hayashi, M. Sumi, Y. Tanaka, M. Goto, K. Inada, I. Taniguchi, M. Shionoya, H. Matsuo, M. Sugiyama and E. Kimura, Inorg. Chim. Acta, 1999, 294, 56.

16 X. Tao, D. W. Stephan and P. K. Mascharak, Inorg. Chem., 1987 26, 754; P. George, G. I. H. Hanania and D. H. Irvin, J. Chem. Soc., $1959,26,2548$.

17 M. N. Brunett and C. K. Johnson, ORTEP-III, Report ORNL-6895, Oak Ridge National Laboratory, Oak Ridge, TN, $1996 .$.

18 M. J. Waring, J. Mol. Biol., 1965, 13, 269.

19 M. Lee, A. L. Rhodes, M. D. Wyatt, S. Forror and J. A. Hartley, Biochemistry, 1993, 32, 4237.

20 J.-U. Rohde, J.-H. In, M. H. Lim, W. W. Brennessel, M. R. Bukouski, A. Stubna, E. Münck, W. Nam and L. Que Jr., Science, 2003, 299 1037.

21 J. C. Quada, M. J. Levy and S. M. Hecht, J. Am. Chem. Soc., 1993, 115, 12171.

22 C. J. Dinsmore, C. B. Zartman, W. F. Baginsky, T. J. O’Neill, K. S. Koblan, I.-W. Chen, D. A. McLoughlin, T. V. Olah and J. R. Huff, Org. Lett., 2000, 2, 3473.

23 Z. Wu, M. E. Fraley, M. T. Bilodeau, M. L. Kaufman, E. S. Tasber, A. E. Balitza, G. D. Hartman, K. E. Coll, K. Rickert, J. Shipman, B. Shi, L. Sepp-Lorenzino and K. A. Thomas, Bioorg. Med. Chem. Lett., 2004, 14, 909.

24 M. P. Singh, S. Sasmal, W. Lu and M. N. Chatterjee, Synthesis, 2000, 1380; C. Hemmert, M. Renz, H. Gornitzka, S. Soulet and B. Meunier, Chem. Eur. J., 1999, 5, 1766.

25 D. D. Perrin, W. L. F. Amarego and D. R. Perrin, Purification of Laboratory Chemicals, Pergamon, Oxford, 2nd edn., 1980.

26 W. Mazurek, K. J. Berry, K. S. Murray, M. J. O’Connor, M. R. Snow and A. G. Wedd, Inorg. Chem., 1982, 21, 3071.

27 G. M. Sheldrick, SHELX-97, A Computer Program for Crystal Structure Solution and Refinement, Universität Göttingen, Göttingen, Germany, 1997.

28 G. M. Sheldrick, SADABS, Version 2. Multi-Scan Absorption Correction Program, Universität Göttingen, Göttingen, Germany, 2001.

29 M. E. Reichman, S. A. Rice, C. A. Thomas and P. Doty, J. Am. Chem Soc., 1954, 76, 3047.

30 J. Bernadou, G. Pratviel, F. Bennis, M. Girardet and B. Meunier, Biochemistry, 1989, 28, 7268 . 